\title{
EDGAR JOHNSON ALLEN
}

\author{
I866-1942
}

The late Dr E. J. Allen was the son of the Rev. Richard Allen, a Wesleyan minister and as such liable to change the sphere of his work every few years. For this reason E. J. Allen passed his childhood in Cornwall, went to school in Exeter, and lived during his late boyhood in the Worth Valley, going into Leeds to attend the Yorkshire College (now University of Leeds); his education was continued by the University of Berlin, an interval of teaching in Antigua, and University College, London, followed by a Royal Society research studentship at the Plymouth Laboratory. Excepting Antigua, every one of these epochs claimed in him its own loyalties: a few years ago he seriously considered going west to Cornwall to end his life where he first remembered it; he much admired Franz Eilhard Schulze, who taught him at Berlin, and W. F. R. Weldon, his Professor of Zoology at University College, yet kept a lively gratitude for what he had learned from Professor Miall at Leeds.

To this very varying environment during the first third of his life we may attribute through the next half-century much of his universal power of sympathy and contact with all sorts and conditions of men. Unselfish by nature, he had the example of a singularly wide-minded father; then bred as a boy in Cornwall, Devon, and West Riding, as a man among London University students and Berlin University students, with the West Indian interludethere was no class or nation who could not feel an understanding with Allen.

I first heard of him from Weldon-probably in I89r. 'I say! I've got a new sort of student at U.C. now-name of Allen. I gave them the classification of the Crustacea, and at the next lecture he brought up to show me, in case anything interested me, a collection of Crustacea he had made in Antigua, showing some he found rather difficult to fit in!' Weldon had always a great regard and very high esteem for Allen: to this I should attribute Allen's whole connection with Plymouth, from his first visit for research in 1892 to his appointment as Director and Hon. Secretary in 1895.

We met in the Laboratory at the end of 1893 . Bles (Director), Cunningham (Naturalist) and Garstang (Assistant Naturalist) were the Staff naturalists; Allen, Hickson, and myself, were the visiting naturalists. Our laboratory assistant was a young man of 22 named Joseph, who was monarch of all he surveyed on the laboratory floor, and was not quite conscious of his own limitations. Roach was our collector and fisherman, an admirable man at that time, who could do anything with the $18 \mathrm{ft}$. open boat, Anton Dohrn, which formed our fleet, always ably seconded by 'Bill', who, as W. Searle, now numbers 50 years of friendship among biologists working at Plymouth. 
Outside his work on the nervous system of the embryonic lobster, Allen had started an experiment on filtering water from the circulation through Berkefeld porcelain filters. It was unsuccessful (he had not coped with the difficulties of keeping the filtrate sterile), but it was his first attempt in 1894 to deal with the problem, which he solved in I9IO, of preparing sea water in which delicate larvae could be reared.

He lodged in Windsor Lane (ground floor on the right hand as you go down from the Hoe, I think the second door). We led quiet and studious lives, and he had a reserve or a shyness which I found difficult to penetrate at that time; looking back, I think a natural shyness was then accentuated as the result of eight years of uphill life in which he had not found the world gentle. Outside work, our greatest excitement was when J. T. Cunningham and his wife asked us to Sunday supper-hospitality most pleasantly given and most gratefully received by two bachelors in lodgings; Mrs Cunningham was a sweet-natured woman. Mrs Bles had a serious illness on her arrival at Plymouth, so that we did not visit the Director's house until later in the year. Hickson, in the laboratory compartment on my left, was the best of neighbours; Garstang was not only a mine of information on the fauna of the Sound but was a source of cheerfulness and good companionship to us all.

In the autumn of I894 Bles gave up the contest, in which he had struggled valiantly and well, and Allen was appointed Director in his place; a place that had now been filled by four Directors in eight years. But Weldon had already confided in me that he thought the constitution of the Association was more to blame for these rapid changes than defective qualifications in the four Directors. The Hon. Secretary was in the habit of making criticisms to the Director and bringing before Council any matters in the conduct of the Laboratory which he considered desirable to be discussed with the Director. In other words it was the Secretary's duty to scratch the Director's back: and E. Ray Lankester scratched Heape's back good and hard, while G. H. Fowler did the same for Calderwood and Bles (G. C. Bourne could look after his own broad back). Remembering also that Allen was Weldon's pupil一and remembering all he did for me, who had also been his pupil-I attribute to Weldon salvation of the M.B.A. by the revolutionary change making Allen the first Director also appointed Honorary Secretary.

So, in January I895, aged 28, Allen took up his duties, with behind him a discouraging Bluebeard's cupboard of ex-Directors, yet holding one immense essential advantage over them: that he had only to deal with the Council and the President, not with an official critic busy in preparing for them a synopsis of his three months' errors.

This was an immense advantage, but even so the prospect was enough to make even a bold man shrink. We had a fine well-designed marine laboratory, with comfortable 'tables' for eleven workers and two or three extra rooms. In December of I893, when Garstang, Allen and Hickson had gone for Christmas holidays, for a week or two Cunningham worked on the north 
side of the Laboratory and I on the south side. The Director left his wife's sick bed to pay us each a diurnal visit, and Cunningham and I kept each other company for the rest of the day.

Financial stringency was dire. Income all in was $£ 1950$ (of which $£ 1000$ was granted annually by the government and $£ 400$ by the Company of Fishmongers). The salaries we paid were beggarly: $£ 200$ a year and a house to the Director, $£ 250$ to the Naturalist, $£ 150$ to the Assistant Naturalist, if there was one, and $£ 350$ in all to pay fishermen, laboratory attendant, engineer and clerk; yet Allen put the necessary minimum expenditure at $£$, 800 without any assistant naturalist. There was the cavern of a Laboratory, weathertight and with pumps going, in which the Director, the Naturalist, and the Assistant Naturalist made their researches while a dozen naturalists visited them during the year, most of them for only a few weeks in the summer.

I came down to Plymouth in July 1895, when Allen had been six months in the saddle. July and December at the Laboratory were very different things and I found a most pleasant company: W. F. R. Weldon, W. Garstang, A. Bethe (Munich), J. D. Gilchrist, T. H. Riches and W. I. Beaumont, with T. V. Hodgson, newly appointed as Director's Assistant, and three undergraduates. Weldon's presence was a great pleasure to Allen and me. He was rearing 500 young crabs through a moult, to ascertain how far deviation from the normal was the same for the old and new carapaces of each crab; Allen had rigged him a perfect apparatus-a sloping rack of shelves under a corrugated iron pent house over the open-air tank at the back of the aquarium. On the shelves were 500 glass jars, each supplied with a jet of sea water and containing a live crab. (It looked so like a display at a grocer's shop that the irreverent referred to it as 'Gubbins \& Co.') Every day each crab was fed with fresh fish, and the cutting of fillets of young soles the moment they. were dead was hard manual labour. I think Weldon's visit lasted out August.

Garstang was no longer on the staff, but a Fellow and Lecturer of Lincoln College, Oxford. He was only down for five weeks, working at Tunicates, but also, as in a previous visit in March, was conducting a most important experiment: the first of 'Garstang's Classes'. This year there were only five pupils, two in March and three in July. 'This is, I am convinced, a useful extension of the work of the Laboratory', writes Allen in his Report to the Council; most zoologists of to-day would agree that the carrying on of these classes by Garstang, Orton, and their successors has been as important a piece of work as any that the Association has done. In the following year fifteen students came at Easter and three in the summer; now, for over 40 years, only war has interrupted the sequence of classes: not only have they been füll to overflowing but so have been the similar classes which have followed them in other marine laboratories. Several thousand biologists must already have benefited from this new departure made by Garstang and Allen in Allen's first year.

Bethe, working at the crustacean nervous system, obviously came to Plymouth to be in the same laboratory as his fellow-worker, Allen, with whom he 
became great friends, as he did with me. I should like to record that with my own microscope, in my own well-examined preparation, when I requested him to recognize, looking down on a collar-cell, the stained cross-section of a flagellum $0.5 \mu$ in diameter, he said, 'Oh yes, stained on its surface, with a white lumen.' Which I could then see, but had not seen.

Late in August E. T. Browne came for a six weeks' visit, lodging over me at 7 Hoe Park Terrace. Browne's company was always very welcome to Allen; they had been at University College together, and I think, to the end, Browne was his most intimate friend and always his staunch ally. He was a learned, industrious and skilful zoologist, with a passion for his medusae. Like Riches, he suffered from the apparent infinity of time before him in which to publish a magnum opus, but he loved zoology, and the prosperity of the Laboratory became one of his greatest interests. He was gentle and much liked.

I had to spend month-ends in London, and on my return on August 3I Allen greeted me with startling news. There was to be a congress of journalists in Plymouth for the third week of September, they might be 400; the local Committee had approached Allen as to.facilities for seeing the Aquarium and he had invited the congress to a soirée.

For a moment my breath stopped as I pictured our poverty-stricken, understaffed Association throwing a party to four hundred strangers-then I saw Allen's genius! He invited them to the most imposing building of the neighbourhood outside the Citadel; in the Aquarium, the great laboratory and adjuncts, there was comfortable walking and standing room for two hundred people, there was that for them to look at which they could not see elsewhere in Britain and nothing in laboratory or aquarium to show our penury. It was a type of all that he did as Director-to see what advantages we had and to use them.

Then he fired his second barrel: 'The difficulty is that since Cunningham went to Grimsby in February, we have no fish expert here. Stead doesn't arrive until the Ioth, and it wouldn't be fair to ask a man fresh from his tripos to take it on when he has only been a week in the laboratory. You will have to be our fish expert.' 'But I know next to nothing about fishes!' 'That doesn't matter, you've got nearly three weeks to learn them up in.' So, with microscope under its bell-jar, for the first half of September I read diligently in Couch and Day and the volumes of our fournal, or wandered round the Aquarium trying to memorize which fish was which.

The Soirée was a complete success-except for the fish expert! I don't think there were much short of two hundred guests, and it all went with a bang. There was a rocker-microtome on which someone cut sections. Browne had a beautiful show of hydroids and medusae, Riches had an appalling nemertine (was it $20 \mathrm{ft}$. long? or only Io?), there were half a dozen other shows, and the tanks lit up in the Aquarium and two or three printed leaflets to take away (I was put on to write one on making sections in paraffin), and every one was hard at it seeing things and all seemed to enjoy themselves. I gave 
lectures at the tanks to twenty or thirty young journalists, who listened eagerly to the carefully prepared stories. Unfortunately, they were joined by dear old Robert Bayly, one of our Governors and benefactors, who knew a good deal about fishes and was anxious to make the most of the opportunity of contact in the Aquarium with the Fish Expert of the Marine Biological Association. When his questions came-though I had not finished my stories-there was nothing for it but to look at my watch, say 'Excuse me, I'm wanted upstairs', and dash through the Director's House into the safety of the great laboratory.

The out-of-pocket expenses were about five pounds. "Allen pleased many scores of people, he put the Laboratory on the map with at least a hundred journalists, he gave dignity to the M.B.A. before the face of Plymouth, and he added valuably to our self-respect.

Beaumont now became for many years the occupier of a table for the greater part of the year. He was a real naturalist, but led more to admire and enjoy than to investigate, and his greatest interest was yachting. At one period I laughed to Allen that I thought Beaumont only used his cubicle as a place in which to eat his lunch. But Allen was quite right to welcome him. He was very kindly and always ready to help anyone; he took his part in tedious identification of dredged samples and in considering problems concerning our boats. Principally, however, I think Allen saw the first urgency of building up a community to be a soul to the body of our buildings. Beaumont was an addition to that community, so was Hodgson. The Council allowed $£ 100$ for an 'Assistant to the Director', which in those days would have got him a good clerk. Instead he engaged, on a half-time basis, Hodgson, who had a job under the town council, as lecturer and later as Museum curator; having recently returned from the Antarctic expedition, on which he had been doing pycnogons and amphipods, he was naturally one of us.

The most important newcomer this year to the Laboratory, after the Director, has not yet been named. He was an old acquaintance of mine, A. J. Smith, who was assistant to Brockett in the Morphological Laboratory at Cambridge. Adam Sedgwick said in the winter: 'I don't know what to do about Smith. $\mathrm{He}$ is too good a man to go on in his present position and I can't offer him anything better. Do you think he would be of use at Plymouth?' I presume that Sedgwick put the same question to Allen, for Smith began in April that career of 45 years through which he incurred the gratitude of every biologist working at Plymouth, and was always the most loyal supporter of the Director. That invaluable addition to our strength we owe to Sedgwick and Allen.

On July 30 Allen made, off Prawle Point, the first four hauls of over a hundred, made with dredges, trawls, etc., during this and the next two years, to determine the relation between fauna and bottom deposits near the 3o-fathom line from Eddystone Grounds to Start. He was enabled to do this by a Royal Society grant of $£$ roo for boat-hire, and the Royal Society must have found his fine Report in 1899 (occupying No. 4 of Vol. $\mathrm{v}$ of our fournal) very ample justification for their assignment of this sum. Nearly everyone working in the 
Laboratory assisted in the determination of the animals brought up, and Allen's friend $\mathrm{R} . \mathrm{H}$. Worth, the engineer and Devon archaeologist and geologist, gave essential help in analysis of the bottom deposits. It was a valuable effort in fundamental research, and the characteristic of the man was the skill with which our meagre resources were marshalled to undertake, and to carry through, such an important piece of team work.

Before I left at Christmas, Allen gave me another job, not involving false colours this time. The Colonial Secretary this year was the Right Hon. Joseph Chamberlain, who had been our champion in obtaining for us from the Government, first $£ 500$ a year and then $£$ rooo a year. (He told me, when I showed him round the Stazione at Naples, that he would have liked to have got more for us, "but you know those fellows Harcourt and the others take no interest in such things'.) It was quite natural, therefore, that he should instruct the Colonial Office to request from the Director of the. M.B.A. a 'Report on Sponge Culture and Projects for the Improvement of Sponge Fisheries'. Allen asked me to look up the thing for him and show him the papers on which to found his Report. I did so, and wrote a note of my own (of which the Appendix may be the best part), and he made a business-like Report on the literature. I have just been re-reading some of his Reports in our fournal of these early years: 'Reproduction of the Lobster', 'Protection of Crabs and Lobsters', 'Fauna and Bottom-deposits' - and thinking what powerful writing there is in them. He does not deal in clichés, what he says he means; where there is a problem he puts to consider it the whole strength of a remarkable mind and writes his own opinion, clearly, logically, and briefly.

Early. in this, his, first year, the new Director made a revolution of farreaching importance, with the object - to which he held tenaciously for 45 years -of enabling workers to rear delicate organisms in the Laboratory. The revolution was no other than a one-man revolt against the Crystal Palace tradition.

I can remember as a child the intense surprise and admiration elicited by the Crystal Palace Aquarium, where Londoners could see, living and moving, 'all' the denizens of the sea. The Crystal Palace was inland, 50 miles from the sea; Lloyd deserves the greatest credit for having designed a successful system whereby the tanks and reservoirs had only to be filled once, and then a few barrels to repair wastage sufficed to keep the exhibition brilliant. But when, shortly afterwards, he made the Brighton Aquarium, he used closely the same plan, which Westminster Aquarium of course followed. More remarkably, when Anton Dohrn founded his great Stazione Zoologica, he applied to Lloyd for advice, and Lloyd insisted that the closed circulation and the dark resting reservoir were essential to success. Lloyd had succeeded, so Dohrn followed his plan exactly, and nearly a quarter of a century after the opening of the Crystal Palace Aquarium, Lankester followed it at Plymouth.

But $(a)$ the Crystal Palace had to have a closed circulation; Brighton, Naples, and Plymouth could take fresh sea water at negligible expense: $(b)$ the 
closed circulation with the dark reservoir succeeded admirably for keeping in life the crabs, sea anemones, and so on, which I remember admiring at the Crystal Palace, or Limulus, a dozen of which they used to show us in the palmy days of the Brighton Aquarium; but you could not rear delicate larvae to be adults in that closed circulation. Allen threw overboard the Lloyd tradition, proclaimed that the less any tank is supplied with used water the better for its inhabitants, supplied the laboratory entirely with water which had never been under its roof before (passing it on to improve the aquarium circulation) and organisms lived in the laboratory which had hitherto been transitory visitors while soles spawned in the aquarium for the first time..

Already under the last directorship an occasional carboy of outside sea water was used in the laboratory, now those who requested it for delicate work had a wooden bucket of sea water brought to them from outside the breakwater, and in 1899 there was a pair of wooden 500 gallon reservoirs built at the top of the little stairs, from which by gravity 'outside water' was led through glass tubes to a few small jets in the laboratory; the cistern being replenished from a tank boat by force-pump.

As years pass the difference between the waters of Plymouth Sound and of the ocean becomes more and more noticeable, while the researches of the marine biologist become more and more delicate. Allen's plan of keeping the first reservoir supplied with high-tide water whenever it ran low had to be modified: it was found that often the Sound water was more poisonous than old Aquarium water, eventually new supplies were only taken rarely and the Aquarium acidity was corrected (I think Pantin devised this) with lime in the reservoir. Outside water in bell-jars took up the part it now plays, but never since Allen's revolution was the visiting naturalist advised to rear his larvae in many-year-old water drawn from Lloyd's resting reservoir.

Only by describing thus in detail the first year of Allen's directorship is it possible to give an idea of the character of the man and the reasons for his great success. One of his gifts it may not have brought out is his great business ability. With all his scientific abilities and knowledge and his passionate scientific interest he was a first-class business man.

He recognized at once that the first need to make the Laboratory live was to have it inhabited, and patiently, continuously, he warred against the desolation of barren tables. But his first year of work showed him another essential necessity: we must have a steamboat of our own. Hired boats, which the Royal Society had enabled him to employ, were too expensive to be used for ordinary collecting; also, even when most suitable, they had less than half the efficiency possible with our own boat, fitted with our own gadgets and our own special stores and a working cabin or deckhouse with tables, shelves, and appliances as"experience proved necessary.

In January 1896 he reports to Council that 'the want at Plymouth which must be put before all others, is that of a suitable boat', 'the effective work of 
the Association could be increased by at least $50 \%$ if a suitable small steamer were in our possession'. On February, 13 I 896 he adds, on the proof, a post-. script to his Report: 'an opportunity of securing a small steam fishing yacht, upon advantageous terms, has presented itself. . .the Council decided it would be advisable to purchase without delay. The yacht, the Busy Bee, of Fowey, is now in our possession.'

She was $60 \mathrm{ft}$. long, $9 \mathrm{ft} .8 \mathrm{in}$. beam, gross tonnage 22.5 -a giant compared with the gallant little Firefly, $38 \mathrm{ft}$. long, which we bought in 1889 and used hard for three years, or her successor Pansy of about the same size, given a bad name and sold again. That the prompt purchase of Busy Bee was wise is fairly proved by the fact that she served us well for five years, increasing our effective work nearer $100 \%$ than $50 \%$. Allen paid $£ 605$ for her, spent about $£ 85$ in giving her a steam winch and other fittings for our work, and sold her in 1901 for $£ 700$.

In 1897 she replaced the hired sailing trawler with which sample periodic trawls had been made in the (nominally) closed bays since October I895. She was a movable centre of work on such occasions, spending a fortnight each at Exmouth, Dartmouth and Falmouth. She worked hard, well and cheaply, but by I90I Allen began to feel her too small. Our researches extended farther and farther into and up and down the Channel, for safety we needed something more powerful and for accommodation something larger; for each reason something beamier.

Keeping a watch on the lists of yachts for sale, Allen at length saw an offer which seemed very likely. The Oithona was a schooner steam yacht, $84 \mathrm{ft}$. long, I $6 \mathrm{ft}$. beam, gross tonnage 69 . Writing from memory, she had been built in 1876 , but her engines were younger, she had been in the hands of a wealthy owner and-which attracted us most-her last cruise was all round Great Britain. A yacht 25 years old is not everyone's meat: she had been on the hard at Southampton all a year, and her price was now very moderate.

I think Allen and Beaumont went over to Southampton to look at her and that then Allen had her surveyed. Everything in her was of the very best quality, but her boiler was near its last legs. Allen bought her, with some small expenses, for $£ 858$. 8s. making $£$ I2. IOs. a ton as against $£ 27$ a ton for Busy Bee with a sound boiler.

There were of course alterations to be paid for, including the essential steam winch and deckhouse laboratory: When they were finished and she got to work, Allen was met by the verdict, "That she is not a good sea boat and cannot be trusted to go far in doubtful weather.' For a vessel which has carried an expensive family all round Britain this seemed a strange conclusion. If it was final we had thrown away our chance-but the circumnavigation was a definite fact. We arranged to make our own judgement and took her out on a short trip when there was a good sailing breeze from the south-west.

There was no doubt, she was a wet ship! We met only little waves, but every one we went into came down on her deck. In a rough sea, clearly she 
would not only be uncomfortable, she would be alarming. We considered the matter carefully, there on board. Since her voyage from Lands End to John o' Groats and back we had added above deck level a heavy winch and a deckhouse. These must be compensated, and to cure her dipping her nose we must lighten the bows.

Her chain cable was coiled absolutely in her eyes, resting on the inner surface of the cutwater. We ordered that to be coiled a few feet farther aft, behind a low bulkhead. There were two rather stouter chains as bowsprit shrouds, we condemned them. Then Allen became relentless-the bowsprit must go and be replaced by a light pole! It was a beautiful spar, and its great length finished her graceful proportions, but he was quite right: with that extreme leverage its great weight was a big load for her fine bows. So we condemned it, and one felt the trim rectified. There was still the question of buoyancy, and we now decided that her mainmast must be replaced by a pole (with the deckhouse she could no longer ship a proper mainsail) and then Allen suddenly condemned the handsome teak panels which lined the bulwarks. It seemed a great pity-but teak is a heavy wood and $200 \times 3 \mathrm{ft}$. of it a weighty deck ornament. I forget the weight that we estimated we were removing, but when we next went on the Oithona her deck remained dry, and she presently took on as her job a triangular voyage with its base over the Continental Shelf.

In her fourth year Allen replaced her long-suffering boiler and gave her a refit costing $£ 847$, so that with the winch, etc. she stood us in $£$ I864. She was worth every penny of it. We worked her for some twenty years and sold her after the War to a Belgian biological station for $£ 775$. She was then due for extensive repairs-boiler-casing gone and boiler not too grand-and with the more extensive voyages we were undertaking (to trace the supplies of water to the Channel) we wanted something that was built to rough it: Allen did not like sending her to rough weather out of soundings. He felt very strongly his responsibility for the lives of those on our ships; he used to arrange for the Huxley to take the winter quarterly voyage when we were still doing the International Investigations.

We parted from the Oithona with great regret, she was a kindly ship.

The Huxley was bought by Allen and me at Grimsby, but I made Allen speak the deciding word as to the price. When she was sold, the profits on the whole transaction founded the 'Ray Lankester Investigatorship'. Salpa was wished on us by the Government and her price fixed. The Huxley, Oithona and Busy Bee were each thoroughly profitable as monetary investments, their purchase having been settled by Dr Allen, the specialist on the nervous system of embryonic crustacea.

I lived at Plymouth for four years (1898-1902), so our friendship became very intimate, the more as I was elected to the Council in 1899, so that we collaborated at the Council table as well as in the Laboratory. In I898 Browne's plungers were in use-the first had been set in motion on September 4 
1897. At this time Allen and Browne were still experimenting on arranging an inverted funnel as a plunger so that it emits at its lowest position'a continuous stream of air-bubbles (now known to be a work of superfluity). The plunger has made a revolution in all aquatic biological laboratory research and made easy what used to be impossible. But few who have not read Browne's paper (f. Mar. Biol. Ass. vol. v, p. I80) appreciate Allen's share in the invention: Browne says, 'It was his suggestions which led to the plunger being worked by such a simple method.' Browne's part was the discovery that the essential to healthy aquatic life is the movement of the water, Allen's part was the siphoned jar for a motor, which put the plunger at the disposal of the humblest laboratory that owns a tap.

Garstang returned in June I897 as Naturalist, starting in that capacity a successful partnership of work with Allen as Director which lasted until, ten years later, Garstang was appointed Professor of Zoology in Leeds University. His lively and original mind helped to develop the fishery side of our investigations, particularly as to the passage of sea water into and up the Channel, to test which he instituted considerable bottle experiments and treated the results with great ingenuity. The following five years saw much good work done at the Laboratory with increasing efficiency and smoothness; but the bitter shortness of funds still continued. With Bles succeeding Calderwood as Director, the receipts for I892-3, deducting donations and composition fees, were $£$ I932. I6s. 6d. In I897-8, the fourth year of Allen's directorship, the receipts after deducting donations and composition fees were fir973. 13s. 2d. and the donations and composition fees deducted were only $£ 65$. 9s. whereas in $1892-3$ they were $£ 226$. 5 s. 6 d.: so that Allen had the spending of $£ \mathrm{r} 60$ less than Calderwood and Bles. Allen had done splendidly; there were twice the number of visiting naturalists, our capable little Busy Bee was working hard, our scanty salaries fund was stretched to cover a small staff, competent although disgracefully ill-paid, all kinds of people were working hard. The fournal shows a very fine output of valuable work, both from staff and visitors. Yet to keep up that great building, with engine, pumps, Laboratory and Aquarium, to keep our fishing yacht collecting, to pay all wages ashore and afloat, the salaries of the Director and Naturalist and anything that we could squeeze out from time to time for additionilal help in investigation, we received still under $£ 2000$; say, the family expenses of two average professional men in Kensington.

In 1899 Allen was getting very much discouraged. It was not only that he had to save candle-ends and starve his staff, it was the absence of prospect of anything better. And indeed five years later the Plymouth income was actually no more, though the gross receipts were $£$ roo higher because of increased sale of specimens and of fishing gear, which involved fully the $£_{1} 100$ in extra expenses. Allen talked to me seriously of throwing it up and earning his money in something that was not heart-breaking-perhaps business? The only post to -which I could have helped him would have been a business one at about 


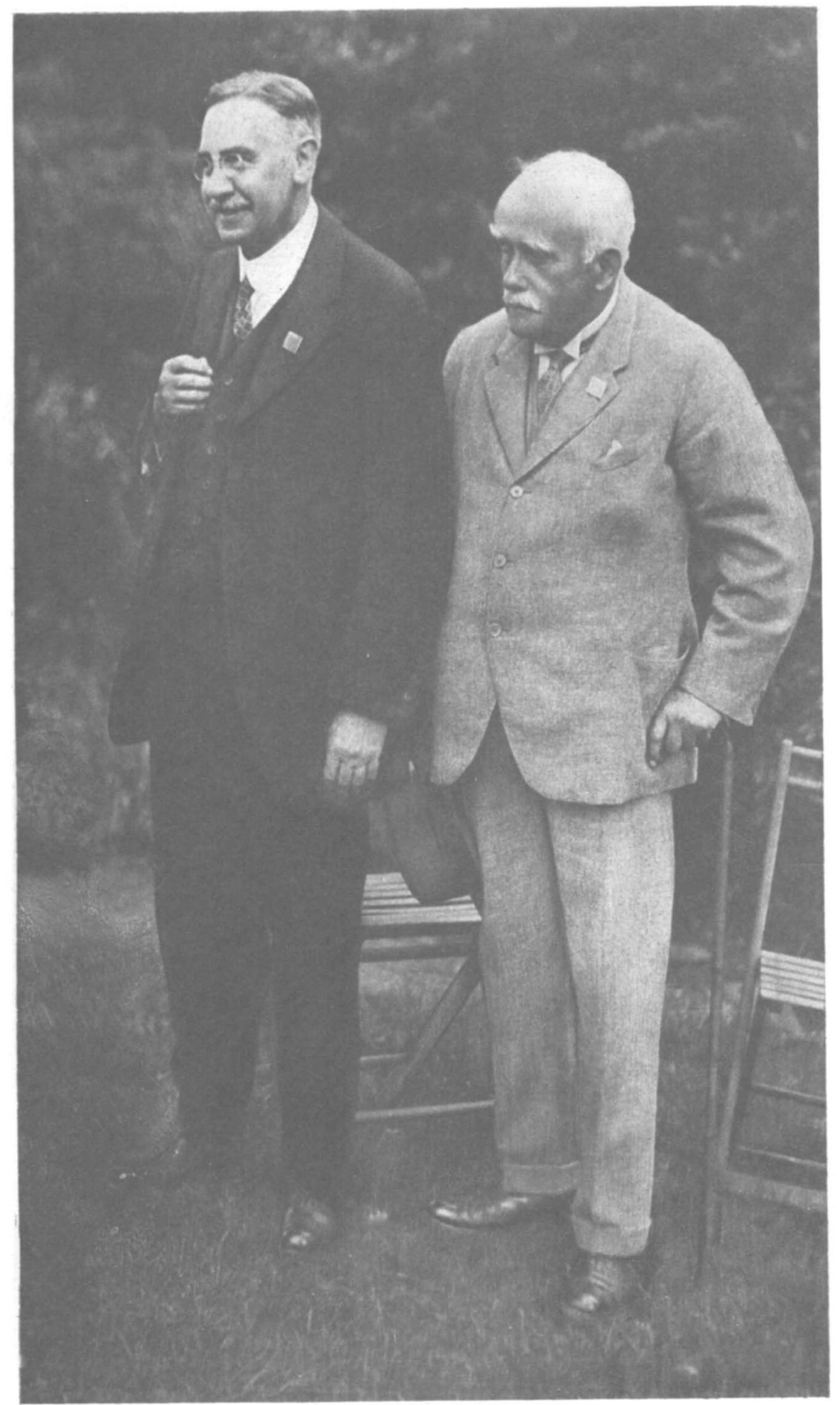

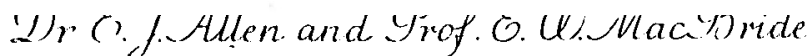
Mritish. Association, Leeds 1927 
Journ. Marine Biol. Assoc., Vol. xxv, p. 680. 
the salary he was earning but not taking a third of the amount of work, so that he would have had more time for researches. To my great relief-as a member of the M.B.A.- this did not tempt him, and he put his neck into the yoke again.

Then in 1902 came the dawn! The Government agreed to take part in the International Exploration of the North Sea, and invited the M.B.A. to undertake England's share in the work for three years, offering us $£, 18,500$ for the whole job. The one saving clause was that in the 6 months to March 3I, I903 we were to receive $£ 7200$, leaving $£$ II,300 (really $£ 5500$ a year) to March $3 \mathrm{I}$, 1905. This enabled us to pay the rent for the Huxley, of $£ 870$ a year, with $£ 2000$ down and $£ 305$ a year in the second and third years, easing the latter years and knocking some $40 \%$ off the cash to be found for purchase of the Huxley; hence the result already recounted. The International Investigation money was of course for the staffing and maintenance of the research vessel and a shore laboratory at the harbour where she was based. Little money came Plymouth way; but Allen was able to give to some of his seamen, as well as to some of his naturalists, a lift up into the Lowestoft staff; a little of the work was done by Plymouth, and in any case we were all part and parcel of the great International Exploration, and no longer a voice crying in the wilderness.

Yet, when it was all over, and Lowestoft handed to the Board of Agriculture and Fisheries, and the Huxley sold; and Garstang teaching at Leeds-we were a little better off, but not much. The Huxley was sold in I9Io and the Development Commission gave us $£ 500$ a year in consideration of our doing some work for the International Investigation which could be better done by us than by the Agriculture and Fishery Board at Lowestoft. The Worshipful Company of Fishmongers now gave us $£ 600$ a year. Allen improved the tank room and receipts increased, more tables were rented, the prices of our specimen trade were increased and it more nearly paid its expenses. In 1914 our total income was close on $£ 3500$; the Director's salary was raised to the princely sum of $£ 300$, but what pleased him much more was that instead of only a Naturalist working under him he now had a Hydrographer, Senior Naturalist, Second Naturalist, Additional Naturalist and Assistant Naturalist. There was nothing grand about the scale of the Laboratory of the Marine Biological Association of the United Kingdom, nor fitting to the dignity of the United Kingdom; but the $70 \%$ addition to our gross income made it a place where one had not the piteous sense of wasted work and opportunity which was so oppressive before 1903: it was modest, and everyone was underpaid, but it was efficient.

Then, after the War, when the other biological stations sent S.O.S. appeals to the Government to save them from extinction, we started building.

Sir W. B. Hardy guided with genius the reorganization of biological effort in Britain to receive the benefits of the Development Fund through the 
Ministry of Agriculture and Fisheries. It was for us the transformation scene of the pantomine. Allen's long labour was at length not in vain, the last third of his Directorship was passed at the head of the leading Marine Biological Station of the world, adequately maintained. The balance-sheet for I926-7 shows as salaries: 'Director $£$ I062. IOs., Physiologist $£$ gro, Naturalists $£ 32 \mathrm{II}$. I 5s. 4d., Hydrographer $\{538.6 s .8 d$.', making in themselves a total of three times the whole expenditure of 1895 .

It was a great happiness to him to be the much loved head of this fine machine. The last time I went round with him as Director there were eighty biologists working in the Laboratory, yet we could both remember its echoing to our footsteps in I894. To have wrought that change was a life's work of which a man might well feel proud.

I have not written of his research. It is not for me to appraise it; that has been done by every reading zoologist and especially by the Councils of the Royal Society and the Linnean Society. I think if he had been working as the Fellow of a College, instead of Director of the Laboratory, he would probably have kept on at the crustacean nerves and other histological work that suggested itself: he had the delight which only the histologist knows in looking with high magnification at the form and structure of cells. Exigencies of his organized survey turned him to polychaetes, and he then became extremely interested in the mysteries of regeneration. The water question-how to keep delicate organisms alive in a laboratory, he regarded as challenging every biologist with its urgency and its difficulty. He had taken up the glove and waged the battle for fifteen years. There again, in dutifully solving the problem obstructing our research, he discovered that no artificial sea water would grow more than a tiny tuft of diatoms, but that if Io c.c. of real sea water were added to the litre and the whole sterilized-then the diatoms filled the jar. Hopkins had just published his 'vitamines' and the comparison interested them both extremely.

I think that in science, as in administration and in business, his leading talent was the rare one of discerning the essential.

But a picture of Allen's intellectual equipment is not given by describing alone the excellence of his research and the insight of his philosophical writing (Presidential Address, British Association, Section D, I922; Hooker Lecture 1929, Proc. Linn. Soc.). Though it never made him dissipate his energies, he had the delightful gift of interest in everything. He said to me once in the 'nineties that people talked a great deal of rubbish about the oppressive mass of zoological literature, that it was perfectly possible to read it all as it came out, more or less carefully according to the paper, and that, so far as the available libraries went, he did it. Thirty years later he said, 'It is now completely impossible'; but the width of his biological reading was equalled by only a few men whom I have known. What you only found out by degrees was the extent to which he kept himself up to date in physiology, chemistry 
and physics; what you might never find out was the amount of his general reading and his keen love of poetry.

Given this mind and this learning, with the invention that devises new methods and new lines of research, adding to it his unlimited sympathy and great unselfishness, it is possible to understand how it was that few of those who worked at Plymouth ever failed to receive valuable help from the Director. His unswervingly honest mind and sensitive kindness made him the ideal critic. In the second and third decades of this century he became really important in the zoological world; I thought at one time that in him we were going to see again someone who could be called the leader of contemporary English zoology -but Lankester was the last who could be given that title and will remain the last. There was, however, no question of the widespread respect and affection shown to Allen wherever zoologists met together, and well-deserved distinctions began now to come fast. F.R.S. in I9I4 was followed by the presidencies of the Devonshire Association in I9I6 and of Section D of the British Association in 1922; a year later Denmark gave him the Hansen Memorial Medal and Prize, three years after that the Linnean Society awarded Allen their Gold Medal and in 1929 he gave their Hooker Lecture. Edinburgh conferred on him the Hon. LL.D.; he was made Foreign Member of the Royal Academy, Denmark; in 1935 he received his C.B.E. followed in 1936 by the Darwin Medal of the Royal Society and the Agassiz Medal for Oceanography from the National Academy of Sciences, Washington. University College, London, elected him a Fellow in I939.

An end comes to everything, and in 1935 he told the Council that he wished to resign. He was sixty-nine and he felt the work too heavy for him. At the Council's request he agreed to stay on to September of the following year, but six weeks before the appointed terminus he was taken seriously ill and had to have an operation. While he was laid aside, his colleagues effected the transfer of his possessions to rooms already chosen in Reservoir House, Skardon Place, belonging to Mrs Sexton, his connexion by marriage as well as a valued colleague and collaborator; so when he left the nursing hostel he moved into his new home. It is a house of the Regency time, with the grace of proportion belonging to its period: the bow windows of his sitting-room looked over the garden to the reservoir; over the roofs beyond the water he saw Staddon Heights and the Sound. The attractive old garden, made pretty by Mrs Sexton's discerning care, is bounded by a low wall which forms the top of the reservoir retaining wall; the place offered a pleasant harbour for last moorings.

Here he set to work to cultivate wood-lice, and found them extremely interesting-as he would have found cockroaches or frogs or mustard and cress. But after two or three years he had to give up research because he found his memory had gone too much (the biographers tell the same of Faraday). When I was last at Plymouth, two years ago, he was hard at work reading modern physics, particularly the text-book just published in joint authorship 
by his brother and his sister's son, Roland Maxwell. 'I forget it all entirely in three months, but that does not spoil the interest.'

He was quietly happy, walking over to the Laboratory several times a week, and in contact with many old friends; but I think he found his rooms a little solitary after having lived a third of a century in the focus of a busy hive. He enjoyed his very occasional sallies up to London to stay with relations and friends and go to a meeting or two. He was up in April 1942 and spent 24th-29th at Cambridge, happy and making others happy. In November he had some bronchial trouble and was poorly the first days of December. By December $4^{\text {th }}$ he seemed to have thrown it all off. He died suddenly and painlessly on the morning of December 7 .

Allen was the best-loved of British zoologists, of whom most hailed him as a personal friend. With a shy manner, he was always unobtrusive and rather silent, always helpful, always transparently honest intellectually and morally, and always kind. He had a delicate reverence for women which they completely appreciated and he was delightful with children, who were all ready to adopt him as a new uncle or grandfather. With all his friendships, however, family affection held the central place with him. Very early in his directorship he brightened the Director's House with a long stay from his fifteen-year-old sister. I often heard of his brothers: it is unusual for two brothers each to be a Fellow of the Royal Society (Professor H. S. Allen, F.R.S., of St Andrews, is his younger brother), but he told me that their eldest brother $\mathrm{Dr} \mathrm{H}$. N. Allen (Principal of the Poonah College of Science), who died in 1932, was abler than either of them. When he received his own F.R.S. in I9I4 and I congratulated him, he said bitterly, 'Why didn't it come when I should have valued it, it is too late now'-the value of such things being to show one's parents. That was temporary, his well-earned honours were not lost on him.

I knew Allen for half a century and I never knew him do a mean thing or a selfish thing. He was understandingly sympathetic and unfailingly helpful. Of all his gifts, his greatest excellency was as a friend.

G. P. B. 